\title{
Effects of Exercise Training on In Vivo Insulin Action in Individual Tissues of the Rat
}

\author{
D. E. James, E. W. Kraegen, and D. J. Chisholm \\ Garvan Institute of Medical Research, St. Vincent's Hospital, Sydney, New South Wales 2010, Australia
}

\begin{abstract}
It has previously been suggested that exercise training leads to increased whole body insulin sensitivity. However, the specific tissues and metabolic pathways involved have not been examined in vivo. By combining the euglycemic clamp with administration of glucose tracers, $\left[{ }^{3} \mathbf{H}\right] 2$-deoxyglucose (2DG), $\left[{ }^{14} \mathrm{Clglucose}\right.$, and $\left[{ }^{3} \mathrm{H} / \mathrm{glucose}\right.$, in vivo insulin action at the whole body level and within individual tissues has been assessed in exercise-trained (ET, running $1 \mathrm{~h} / \mathrm{d}$ for $7 \mathrm{wk}$ ) and sedentary control rats at four insulin doses. Whole body insulin sensitivity was significantly increased in ET. In addition, the skeletal muscles, soleus, red and white gastrocnemius, extensor digitorum longus (EDL), and diaphragm all showed increased sensitivity of insulin-stimulated 2DG uptake with training. With the exception of EDL, no significant difference in insulinmediated glycogen synthesis between control and ET could be found. Therefore, the increased insulin-induced 2DG uptake observed in muscle following training is apparently directed towards glucose oxidation. In ET animals, adipose tissue exhibited a significant increase in insulin-mediated 2DG uptake and $\left[{ }^{14} \mathrm{Clglucose}\right.$ incorporation into free fatty acids but there was no difference from control in any parameters measured in lung or liver. EDL and white gastrocnemius, which are not primarily involved during exercise of this type, also demonstrated increased insulin sensitivity following training. In conclusion, exercise training results in a marked increase in whole body insulin sensitivity related mainly to increased glucose oxidation in skeletal muscle. This effect may be mediated by systemic as well as local factors and is likely to be of therapeutic value in pathological conditions exhibiting insulin resistance.
\end{abstract}

\section{Introduction}

Exercise training in both man and the rat may result in improved whole body insulin sensitivity $(1,2)$. This chronic adaptation to exercise has obvious implications in insulinresistant states such as Type II diabetes. However, the nature and locus of the effect remain poorly defined. In fact, there is very little information about the relative effect of exercise training on insulin sensitivity in different tissues of the body.

It has been demonstrated that both skeletal muscle and adipose tissue from exercise trained animals exhibit significant

\footnotetext{
Address reprint requests to Dr. James.

Received for publication 26 November 1984 and in revised form 18 March 1985.
}

\section{J. Clin. Invest.}

(C) The American Society for Clinical Investigation, Inc. 0021-9738/85/08/0657/10 $\$ 1.00$

Volume 76, August 1985, 657-666 increases in insulin-mediated glucose metabolism (3-9), but even this limited information, obtained using isolated systems or in vitro techniques, may not accurately reflect the in vivo response.

A number of specific issues also require clarification. First, there is the question of whether the improvement in insulin action is a systemic effect or is localized to the exercising muscle. Second, it has not been determined whether the effect is one of improved sensitivity or responsiveness or both. Third, it must be determined whether the enhanced glucose assimilation in muscle is directed towards oxidation or glycogen synthesis. Finally, there is the question of whether the effect is entirely related to the impact of the last bout of exercise rather than to the training program itself.

Attempts to classify the whole body insulin response into individual tissue responses have been made in man by various adaptations of the glucose clamp technique $(10,11)$. However, these have been limited by tissue accessibility. We have previously described a technique combining the euglycemic hyperinsulinemic clamp with administration of various glucose tracers for studying in vivo insulin action at the whole body level and within individual tissues of the conscious unrestrained rat (12). In the present studies we have used this technique to study the effects of prolonged exercise training in vivo insulin action with a number of different tissues.

\section{Methods}

Experimental animals. Male Wistar rats bred and raised in our own colony, with free access to food and water and subject to controlled lighting (lights on from 0600 to $1800 \mathrm{~h}$ ), were used for study. All animals were between 90 and $120 \mathrm{~d}$ old at the time of study. Sedentary control and exercise-trained animals were housed under identical conditions. Animals were exercise trained for 7 wk using a rodent treadmill (2). The duration and speed of running were gradually increased during the initial 3 wk after which animals were running continuously for $1 \mathrm{~h} / \mathrm{d}$ at $21 \mathrm{~m} / \mathrm{min}$ (inclination set at $10^{\circ}$ ) for the remainder of the training schedule. Exercise-trained rats were studied $\sim 50 \mathrm{~h}$ after the last bout of exercise. Both control and exercise-trained rats were deprived of food for $5 \mathrm{~h}$ before the commencement of study at $\sim 10$ a.m.

Euglycemic clamp studies. Control and exercise-trained rats were anesthetized with pentobarbitone $(20 \mathrm{mg} / \mathrm{kg}$ i.p.) and ketamine hydrochloride $(25 \mathrm{mg} / \mathrm{kg}$ i.m.) and fitted with two chronic intravenous cannulae as previously described (13). Studies were conducted $48 \mathrm{~h}$ after surgery in unrestrained conscious rats. This time was chosen for the following reasons: $(a)$ to avoid acute effects due to the last bout of exercise (14); (b) to allow the animals to overcome surgical stress and adapt to the cannulation preparation (13); and (c) to minimize the loss of animals from the study through blocked cannulae.

Euglycemic hyperinsulinemic clamps were performed as described previously (13). Briefly, a continuous infusion of porcine insulin (Actrapid, Novo Industri A/S, Bagsvaerd, Denmark) was given at various doses to achieve plasma insulin concentrations through the physiological range and up to levels achieving maximal responses. This 
infusion was maintained for $2 \mathrm{~h}$. The arterial blood glucose concentration was clamped at the basal fasting level using a variable rate dextrose infusion. The glucose infusion rate during the second hour of the clamp (GIR $\mathbf{G 0 - 1 2 0}^{1}$ was taken as the steady state whole body glucose disposal rate. Blood samples $(0.4 \mathrm{ml})$ were obtained for insulin determination in all clamp studies at 0,60 , and $120 \mathrm{~min}$. The erythrocytes were resuspended in $0.9 \%$ saline and returned to the animal as previously described (13).

Study A: In vivo insulin action in individual tissues. A total of 65 rats were used in this study in which insulin was infused at either 0 , $1.4,3.6$, or $72 \mathrm{mU} / \mathrm{kg}$ per min in both control and trained rats. Insulin action within individual tissues in vivo was studied as described previously (12). The nonmetabolizable glucose analog 2,6-[ $\left.{ }^{3} \mathrm{H}\right] 2$-deoxyglucose $(50 \mu \mathrm{Ci})\left(\left[{ }^{3} \mathrm{H}\right] 2 \mathrm{DG}\right)$ and $\mathrm{D}-\left[\mathrm{U}-{ }^{14} \mathrm{C}\right]$ glucose $(30 \mu \mathrm{Ci})$ were administered together as an intravenous bolus at $75 \mathrm{~min}$ after the commencement of the study. Blood samples $(125 \mu \mathrm{l})$ for determination of blood and plasma glucose concentrations and plasma tracer concentrations were obtained at 2, 5, 10, 15, 20,30, and $45 \mathrm{~min}$ after bolus administration. The sampling procedure used in these studies (13) results in a loss of $\sim 5 \%$ of the total erythrocyte volume in the rat over the 2-h period of study. At the completion of the clamp, rats were anesthetized (pentobarbitone, $60 \mathrm{mg} / \mathrm{kg} \mathrm{i.v.)} \mathrm{and} \mathrm{the} \mathrm{following}$ hindquarter muscles were rapidly removed and frozen for subsequent analysis: soleus (containing mainly slow-twitch oxidative fibers), superficial or white part of the gastrocnemius (containing mainly fast-twitch glycolytic fibers), deep red part of the medial head of the gastrocnemius (containing mainly fast-twitch oxidative-glycolytic fibers), and extensor digitorum longus (EDL) (containing a mixture of fast-twitch red and white fibers, but predominantly fast-twitch glycolytic fibers) $(15,16)$. In addition, the following tissues were rapidly removed from the trunk of the animal and frozen: liver, diaphragm, lung, heart, and epididymal fat pads.

An estimate of tissue glucose metabolic rate (the glucose metabolic index $\left[\mathrm{Rg}^{\mathrm{g}}\right]$ ) was calculated using the following expression (12):

$\operatorname{Rg}^{\prime}(\mu \mathrm{mol} / 100 \mathrm{~g} / \mathrm{min})=\frac{\mathrm{C}_{\mathrm{p}} \times \mathrm{C}_{\mathrm{m}^{*}(45)}}{\int_{0}^{45} \mathrm{C}_{\mathrm{p}}^{*}(t) \mathrm{d} t}$

where $C_{p}$ is the plasma glucose level during the euglycemic clamp; $\mathrm{C}_{\mathrm{m}^{*}(45)}$ is the tissue accumulation per unit wet tissue mass of $\left[{ }^{3} \mathrm{H}\right] 2$ deoxyglucose-6-phosphate at $45 \mathrm{~min}$ after tracer administration; $\int_{0}^{45} C_{p}{ }^{*}(t) d t$ is the area under the plasma $\left[{ }^{3} \mathrm{H}\right] 2 \mathrm{DG}$ curve over the 45min period following tracer administration; $t=0$, when the tracer bolus is administered.

The incorporation of circulating glucose into storage products in the liver was calculated from ${ }^{14} \mathrm{C}$-incorporation into total nonpolar lipid and into liver glycogen, expressed as a fraction $\left(C_{f}\right)$ of the total clearance of $\left[{ }^{14} \mathrm{C}\right]$ glucose from plasma over the $45-\mathrm{min}$ period following tracer administration.

A detailed description of the tracer methodology and the assumptions involved in calculating $\mathbf{R g}^{\prime}$ and $\mathrm{C}_{\boldsymbol{f}}$ in individual tissues has been reported in detail elsewhere (12). In particular, the integral in Eq. 1 was evaluated using a double exponential fit to the plasma tracer curve.

Glycogen content (micromoles per gram) in liver and soleus was measured in frozen tissue samples from each animal.

Study B: Endogenous glucose production (Ra) and glucose storage. To conduct a more extensive investigation of the influence of exercise training on $\mathrm{Ra}$, muscle glycogen synthesis, and liver and adipose tissue lipid synthesis during the euglycemic clamp, studies were performed in a further 23 animals.

1. Abbreviations used in this paper: ANOVA, analysis of variance; 2DG, 2-deoxyglucose; $\mathrm{ED}_{50}$, half-maximal insulin concentration; $\mathrm{EDL}$, extensor digitorum longus; $\mathrm{GIR}$, glucose infusion rate; $\mathrm{Ra}$, endogenous glucose production rate; $\mathbf{R g}^{\prime}$, glucose metabolic index.
$\mathrm{Ra}$ in the basal state and during a glucose clamp at a single insulin dose was assessed by an infusion of $\left[3-{ }^{3} \mathrm{H}\right]$ glucose (Amersham Corp., Arlington Heights, IL) in control and exercise-trained animals administered via the venous catheters as an initial priming dose $(50 \mu \mathrm{Ci})$ followed immediately by a continuous infusion at a rate of $0.4 \mu \mathrm{Ci}$ / min. A steady state of glucose specific activity in the basal state was achieved by $60 \mathrm{~min}$. Blood samples were obtained at $60,70,80$, and $90 \mathrm{~min}$ after the commencement of the tracer infusion for determination of basal plasma glucose specific activity. From $90 \mathrm{~min}$, animals were infused with insulin $(2.4 \mathrm{mU} / \mathrm{kg}$ per $\mathrm{min})$, while blood glucose was maintained at euglycemia for a further $2 \mathrm{~h}$. The $\left[3-{ }^{3} \mathrm{H}\right]$ glucose infusion was continued at $0.4 \mu \mathrm{Ci} / \mathrm{min}$. Plasma insulin concentration, glucose infusion rate, and glucose specific activity had all reached steady state by $60 \mathrm{~min}$ after the commencement of the clamp, after which four blood samples $(0.1 \mathrm{ml})$ were obtained at 10 -min intervals for measurement of glucose specific activity. Ra was calculated as follows:

$\mathbf{R a}=\mathbf{R i}+\mathbf{R a}^{*} / \mathrm{sp} \mathbf{a c t}_{(\mathrm{Glu})}=\mathbf{R d}$ at steady state

where $\mathrm{Ra}^{*}$ is the tracer infusion rate in disintegrations per minute; $\mathbf{R i}$ is exogenous glucose infusion rate ( 0 in the basal state); $\mathbf{s p}$ act $_{(\mathrm{Glu})}$ is the steady state value of plasma glucose; and $R d$ is the rate of peripheral glucose disposal.

To study glycogen synthesis in different muscles and glucose conversion to the esterified free fatty acid (FFA) moiety of the total lipid extract in liver and adipose tissue, the above animals also received a bolus injection of $\mathrm{D}-\left[\mathrm{U}-{ }^{14} \mathrm{C}\right]$ glucose $(80 \mu \mathrm{Ci}) 45 \mathrm{~min}$ before the completion of the study. In addition, studies were performed in other animals either under basal conditions (no exogenous insulin or $\left[{ }^{3} \mathrm{H}\right]$ glucose) or infused with insulin at $2.4 \mathrm{mU} / \mathrm{kg}$ per min (no constant $\left[{ }^{3} \mathrm{H}\right]$ glucose infusion). The experimental protocol was essentially the same as that described in study A except that particular care was taken to remove all tissues as rapidly as possible (17). The following tissues were removed at the completion of this study: soleus, red gastrocnemius, white gastrocnemius, EDL, liver, and epididymal fat pads. All tissue samples were stored at $-70^{\circ} \mathrm{C}$ until analyzed.

The rate of muscle glycogen synthesis from glucose was calculated as previously described (17). The calculation was analogous to Eq. 1 for $\mathrm{Rg}^{\prime}$.

$\left[{ }^{14} \mathrm{C}\right]$ glucose into glycogen $(\mu \mathrm{mol} / 100 \mathrm{~g} / \mathrm{min})=\frac{\mathrm{C}_{\mathrm{p}} \times \mathrm{C}_{\mathrm{G}^{*}(45)}}{\int_{0}^{45} \mathrm{C}_{\mathrm{p}}^{*}(t) \mathrm{d} t}$

where $C_{p}$ is the steady state plasma glucose concentration (micrograms per milliliter); $\mathrm{C}_{\mathrm{G}^{*}(45)}$ is $\left[{ }^{14} \mathrm{C}\right] \mathrm{glycogen}$ in muscle (disintegrations per minute per milligram wet weight) at $t=45 \mathrm{~min} ; \mathrm{C}_{\mathrm{p}}^{*}(t)$ is plasma $\left[{ }^{14} \mathrm{C}\right]$ glucose concentration (disintegrations per minute per milliliter); and $t=0$ when the tracer bolus is administered.

$\left[{ }^{14} \mathrm{C}\right]$ glucose incorporation into total lipid extracts of epididymal adipose tissue and liver were also measured in this study. An aliquot of the total nonpolar lipid extract was taken for counting in addition to the saponified FFA extract. The difference between the amounts of radioactivity incorporated into total lipids and FFA can be regarded as representing the synthesis of glyceride glycerol because the incorporation into the nonsaponifiable fraction was negligible (18). Results are expressed as the fractional clearance $\left(C_{f}\right)$ (percent per gram of tissue) of the total $\left[{ }^{14} \mathrm{C}\right]$ glucose dose administered (12).

Analytical methods. Plasma samples for determination of tracer concentration were deproteinized immediately in $5.5 \% \mathrm{ZnSO}_{4}$ and saturated $\mathrm{Ba}(\mathrm{OH})_{2}$. An aliquot of the supernatant was added to scintillant for counting in a liquid scintillation spectrometer. To measure plasma $\left[{ }^{3} \mathrm{H}\right]$ glucose, supernatants were dried down at $60^{\circ} \mathrm{C}$ before counting to remove any ${ }^{3} \mathrm{H}_{2} \mathrm{O}$. Blood and plasma glucose concentrations were measured using a Yellow Springs glucose analyzer (YSI 32AM; Yellow Springs Instrument Co., Yellow Springs, Ohio). Plasma samples for insulin determination were stored at $-20^{\circ} \mathrm{C}$ until analyzed by a double antibody radioimmunoassay (19) as described 
Table I. Body Weight and Plasma Data in Control and Exercise-trained Rats

\begin{tabular}{lcc}
\hline & Control & Exercise-trained \\
\hline Body weight $(g)$ & $345 \pm 1 \quad(47)$ & $315 \pm 1 \quad(38)^{*}$ \\
Basal insulin $(m U / l i t e r)$ & $32.5 \pm 1.9(46)$ & $22.9 \pm 1.5(34)^{*}$ \\
Basal blood glucose & & \\
$\quad(m m o l / l i t e r)$ & $4.1 \pm 0.1(46)$ & $4.1 \pm 0.1(34)$ \\
Basal corticosterone & $192 \pm 38(25)$ & $145 \pm 22(19)$ \\
\hline
\end{tabular}

All values are means \pm SEM. The number of observations is shown in parentheses. Basal refers to 5-h fasted animals.

* Significantly different from sedentary control group, $P<0.005$.

previously (13). Corticosterone was assayed by a nonextracted method similar to that used by Carr et al. (20). Glycogen and $\left[{ }^{14} \mathrm{C}\right]$ glycogen were estimated essentially according to the method of Chan and Exton (21) as previously described (17). $\left[{ }^{14} \mathrm{C}\right]$ Glucose incorporation into total nonpolar lipids in liver and adipose tissue were measured according to the method of Stauffacher and Renold (22). In some studies, the fatty acid component of the total nonpolar lipid extract was isolated for determination of radioactivity (18). Hexokinase was assayed at $20^{\circ} \mathrm{C}$ as described by Shonk and Boxer (23).

All counting of radioactivity was performed in a liquid scintillation spectrometer (Beckman Instruments, Fullerton, CA) using a quenchcorrected (external standard) dual-labeled counting program. Radioactivity in aqueous samples was counted in Picofluor scintillant (Packard Instrument Co., Downers Grove, IL). A toluene-based mixture containing 2,5-diphenyloxazole and 1,4-bis(5-phenyloxazol-2-yl)benzene was used for nonaqueous counting.

Other calculations. A computer program, ALLFIT (24), was used to fit a four parameter logistic equation to dose-response curves for $\mathbf{R g}^{\prime}$ in individual tissues. The two parameters which were derived from this equation were the half-maximal insulin concentration $\left(E D_{s 0}\right)$ and $\mathbf{R g}^{\prime}$ at maximal insulin stimulation. All fits were made to individual data points.

Statistics. Statistical analysis was performed using analysis of variance (ANOVA) followed by a Student's $t$ test for paired comparisons where appropriate.

\section{Results}

Table I displays body weight and basal plasma data for control and exercise-trained rats used in these studies. The effectiveness of the exercise training program in these animals is indicated by a significant reduction in body weight $(P<0.005)$ and in basal 5-h fasting insulin levels $(P<0.005)$ compared with the sedentary control animals. There was no significant difference in basal glucose and corticosterone levels between control and trained rats. The mean corticosterone levels in both groups compare well with normal values previously obtained from uncannulated rats at a similar time of day in our laboratory (13).

\section{Study A: Euglycemic hyperinsulinemic clamp}

Table II shows blood and plasma data relevant to the performance of euglycemic clamps for animals used in Study A. There was no significant difference between basal fasting blood glucose and the steady state blood glucose levels achieved during the clamp in the eight subgroups studied. Furthermore, basal blood glucose values and steady state values were similar in all subgroups (Table II). The coefficient of variation of steady state blood glucose levels between 60 and $120 \mathrm{~min}$ ranged from $5.4 \pm 1.6$ to $7.4 \pm 0.8 \%$ in the insulin infusion groups. Fasting insulin levels were generally lower in trained rats reflecting the overall data reported in Table I. Plateau insulin levels produced by insulin infusion were similar at each successive insulin dose in exercise-trained and control rats (Table II). The steady state exogenous glucose infusion rate between 60 and 120 min $\left(G R_{60-120}\right)$ required to maintain euglycemia was significantly higher at insulin infusion rates of 1.4 $\mathrm{mU}(\mathrm{kg} \cdot \mathrm{min})^{-1}(P<0.01)$ and $3.6 \mathrm{mU}(\mathrm{kg} \cdot \mathrm{min})^{-1}(P$ $<0.001$ ) in exercise-trained rats. However, there was no significant difference in GIR $_{60-120}$ between control and exercise-trained rats at maximal insulin doses (Table II).

Plasma tracer disappearance. To calculate parameters describing the effect of hyperinsulinemia on tissue glucose metabolism, it was necessary to quantitate the areas under the plasma tracer disappearance curves for each animal. Table III displays mean areas under plasma disappearance curves from 0 to $45 \mathrm{~min}$ for $\left[{ }^{3} \mathrm{H}\right] 2 \mathrm{DG}$ and $\left[{ }^{14} \mathrm{C}\right]$ glucose at each insulin dose in control and exercise-trained rats. The rate of $\left[{ }^{14} \mathrm{C}\right]$ glucose disappearance was significantly higher $(P<0.05)$ in exercise-trained rats at insulin infusion rates of 1.4 and $3.6 \mathrm{mU}(\mathrm{kg} \cdot \mathrm{min})^{-1}$. Similarly, $\left[{ }^{3} \mathrm{H}\right] 2 \mathrm{DG}$ disappearance was higher in trained animals $(P<0.025)$ at an

Table II. Summary of Blood Glucose and Plasma Insulin Concentrations, and Steady State GIRs in Control and Exercise-trained Rats

\begin{tabular}{|c|c|c|c|c|c|c|c|}
\hline & \multirow[b]{2}{*}{ Insulin infusion } & \multirow[b]{2}{*}{ No. } & \multicolumn{2}{|c|}{ Blood glucose concentration } & \multicolumn{2}{|c|}{ Plasma insulin concentration } & \multirow[b]{2}{*}{ GIR } \\
\hline & & & Fasting & Steady state & Fasting & Steady state & \\
\hline & $m U \cdot(k g \cdot \min )^{-1}$ & & $\mathrm{mmol} \cdot$ liter $^{-1}$ & $\mathrm{mmol} \cdot$ liter $^{-1}$ & $m U \cdot l i t e r$ & $m U \cdot$ liter $^{-1}$ & $m g \cdot(k g \cdot m i n)^{-1}$ \\
\hline \multirow[t]{4}{*}{ Control } & 1.4 & 7 & $4.1 \pm 0.1$ & $4.3 \pm 0.2$ & $35 \pm 6$ & $56 \pm 4$ & $8.4 \pm 0.8$ \\
\hline & 3.6 & 8 & $4.1 \pm 0.1$ & $4.2 \pm 0.1$ & $37 \pm 6$ & $138 \pm 8$ & $13.8 \pm 0.7$ \\
\hline & 14 & 6 & $4.2 \pm 0.1$ & $4.2 \pm 0.1$ & $34 \pm 4$ & $670 \pm 40$ & $26.1 \pm 1.0$ \\
\hline & 72 & 4 & $4.4 \pm 0.1$ & $4.2 \pm 0.1$ & $31 \pm 6$ & $7,500 \pm 350$ & $28.2 \pm 1.5$ \\
\hline \multicolumn{8}{|l|}{ Exercise- } \\
\hline \multirow[t]{4}{*}{ trained } & 1.4 & 6 & $3.9 \pm 0.1$ & $4.1 \pm 0.1$ & $22 \pm 2$ & $43 \pm 3$ & $12.4 \pm 1.2^{*}$ \\
\hline & 3.6 & 9 & $4.3 \pm 0.2$ & $4.2 \pm 0.1$ & $26 \pm 3$ & $126 \pm 6$ & $19.7 \pm 0.8 \ddagger$ \\
\hline & 14 & 6 & $4.2 \pm 0.2$ & $4.3 \pm 0.1$ & $27 \pm 4$ & $670 \pm 30$ & $28.7 \pm 0.6$ \\
\hline & 72 & 5 & $4.2 \pm 0.1$ & $4.2 \pm 0.1$ & $26 \pm 3$ & $7,400 \pm 390$ & $32.2 \pm 2.8$ \\
\hline
\end{tabular}

All values represent the mean \pm SEM of basal or 60 -120-min period. Significantly different from control group: ${ }^{*} P<0.01, \ddagger P<0.001$. 
insulin infusion rate of $1.4 \mathrm{mU}(\mathrm{kg} \cdot \mathrm{min})^{-1}$ (Table III). There was no significant difference in plasma disappearance of either tracer between control and exercise-trained rats in the basal state or at maximal insulin infusion rates. These data confirm the increased whole body glucose disposal rate in exercise-trained rats as reported in Table II.

The concentration of $\left[{ }^{3} \mathrm{H}\right] 2 \mathrm{DG}$ in plasma at $45 \mathrm{~min}$ after tracer administration is also shown in Table III. $\left[{ }^{3} \mathrm{H}\right] 2 \mathrm{DG}$ in plasma just before tissue removal was significantly lower in exercise-trained rats at insulin infusion rates of $1.4,3.6$, and $14 \mathrm{mU}(\mathrm{kg} \cdot \mathrm{min})^{-1}$. Also, Table III shows the mean plasma glucose values, obtained during the 75120-min tracer period, which were used in the calculation of the tissue metabolic index ( $\mathrm{Rg}^{\prime}$ using Eq. 1). In accordance with blood glucose data reported in Table II, mean plasma glucose values were similar at each insulin dose.

Effects of exercise training in skeletal muscle. The effect of exercise training on the $\mathbf{R g}^{\prime}$ in different skeletal muscles in vivo is shown in Fig. 1. Under basal conditions, despite a significant reduction in plasma insulin levels $(P<0.05)$ in exercise-trained rats; there was no significant difference in $\mathrm{Rg}^{\prime}$ compared with controls in any skeletal muscle tested. Dose-response curves of plasma insulin versus $\mathbf{R g}^{\prime}$ were significantly different following exercise training in soleus $(F=3.11, \quad P<0.01), \quad$ red gastrocnemius $(F=2.55$, $P<0.025)$, EDL $(F=2.19, P<0.05)$, and diaphragm $(F=2.12, P<0.05)$ when compared with respective control data using ANOVA (Fig. 1).

The ability of insulin to stimulate $\mathbf{R g}^{\prime}$ was increased following exercise training in all skeletal muscles tested (Fig. 1). This was primarily due to increased insulin sensitivity as indicated by the decline in $\mathrm{ED}_{50}$ values in exercise-

Table III. Areas under Plasma $\left[{ }^{3} \mathrm{H}\right] 2 \mathrm{DG}$ and $\left[{ }^{14} \mathrm{C}\right]$ Glucose Curves, and Plasma Glucose Concentration during the Euglycemic Clamp at Different Insulin Doses in Control and Exercise-trained Rats

\begin{tabular}{|c|c|c|c|c|c|}
\hline \multirow{2}{*}{$\begin{array}{l}\text { Insulin } \\
\text { infusion }\end{array}$} & \multirow[b]{2}{*}{ Group } & \multirow{2}{*}{$\begin{array}{l}\text { 45-min } \\
{\left[{ }^{3} \mathrm{H}\right] 2 \mathrm{DG}}\end{array}$} & \multicolumn{2}{|c|}{ Area under tracer curve } & \multirow{2}{*}{$\begin{array}{l}\text { Mean plasma } \\
\text { glucose } 75-120\end{array}$} \\
\hline & & & {$\left[{ }^{3} \mathrm{H}\right] 2 \mathrm{DG}$} & {$\left[{ }^{14} \mathrm{C}\right]$ glucose } & \\
\hline \multicolumn{2}{|c|}{$m U \cdot(\mathrm{kg} \cdot \min )^{-1}$} & $\begin{array}{l}(\mathrm{dpm} / \mathrm{ml}) \\
\times 10^{4}\end{array}$ & \multicolumn{2}{|c|}{$(\mathrm{dpm} / \mathrm{ml})(\mathrm{min}) \times 10^{6}$} & $\mathrm{mmol} \cdot$ liter $^{-1}$ \\
\hline 0 & $\begin{array}{l}\text { Control } \\
\text { ET }\end{array}$ & $\begin{array}{l}20.5 \pm 1.5 \\
21.2 \pm 1.1\end{array}$ & $\begin{array}{l}21.5 \pm 1.3 \\
22.6 \pm 0.8\end{array}$ & $\begin{array}{l}35.7 \pm 2.7 \\
34.5 \pm 0.8\end{array}$ & $\begin{array}{l}6.5 \pm 0.1 \\
6.6 \pm 0.2\end{array}$ \\
\hline 1.4 & $\begin{array}{l}\text { Control } \\
\text { ET }\end{array}$ & $\begin{array}{l}17.5 \pm 1.8 \\
11.4 \pm 1.4 \ddagger\end{array}$ & $\begin{array}{l}20.8 \pm 0.9 \\
15.9 \pm 1.4 \ddagger\end{array}$ & $\begin{array}{l}26.6 \pm 2.0 \\
20.5 \pm 1.6^{*}\end{array}$ & $\begin{array}{l}6.9 \pm 0.1 \\
6.4 \pm 0.2\end{array}$ \\
\hline 3.6 & $\begin{array}{l}\text { Control } \\
\text { ET }\end{array}$ & $\begin{array}{l}9.3 \pm 0.5 \\
6.7 \pm 0.5^{*}\end{array}$ & $\begin{array}{l}15.7 \pm 0.7 \\
13.9 \pm 0.6\end{array}$ & $\begin{array}{l}20.2 \pm 1.7 \\
16.2 \pm 0.8^{*}\end{array}$ & $\begin{array}{l}6.5 \pm 0.1 \\
6.3 \pm 0.1\end{array}$ \\
\hline 14 & $\begin{array}{l}\text { Control } \\
\text { ET }\end{array}$ & $\begin{array}{l}6.2 \pm 0.1 \\
5.3 \pm 0.2^{*}\end{array}$ & $\begin{array}{l}11.5 \pm 0.4 \\
11.2 \pm 0.4\end{array}$ & $\begin{array}{l}12.9 \pm 0.8 \\
12.2 \pm 0.5\end{array}$ & $\begin{array}{l}6.6 \pm 0.2 \\
6.6 \pm 0.1\end{array}$ \\
\hline 72 & $\begin{array}{l}\text { Control } \\
\text { ET }\end{array}$ & $\begin{array}{l}4.8 \pm 0.3 \\
4.4 \pm 0.1\end{array}$ & $\begin{array}{r}10.5 \pm 0.9 \\
9.6 \pm 0.2\end{array}$ & $\begin{array}{l}11.4 \pm 0.6 \\
10.4 \pm 0.4\end{array}$ & $\begin{array}{l}6.8 \pm 0.1 \\
6.5 \pm 0.2\end{array}$ \\
\hline
\end{tabular}

ET, exercise-trained. $\left[{ }^{3} \mathrm{H}\right] 2 \mathrm{DG}$ and $\left[{ }^{14} \mathrm{C}\right] \mathrm{glucose}$ were administered together as a bolus $75 \mathrm{~min}$ after commencement of the clamp. $45-\mathrm{min}\left[{ }^{3} \mathrm{H}\right] 2 \mathrm{DG}$ represents the $\left[{ }^{3} \mathrm{H}\right] 2 \mathrm{DG}$ concentration in plasma at $45 \mathrm{~min}$ after tracer administration normalized for a tracer dose of $10^{8} \mathrm{dpm}$. Areas were estimated from frequent arterial blood samples over the subsequent 45 -min period using a double exponential equation (12). All areas have been normalized for a tracer dose of $10^{8} \mathrm{dpm}$. Values represent mean \pm SEM. Group sizes and plasma insulin data are shown in Table II.

Significantly different from control at same insulin infusion rate: ${ }^{*} P$ $<0.05 ; \ddagger P<0.025$.

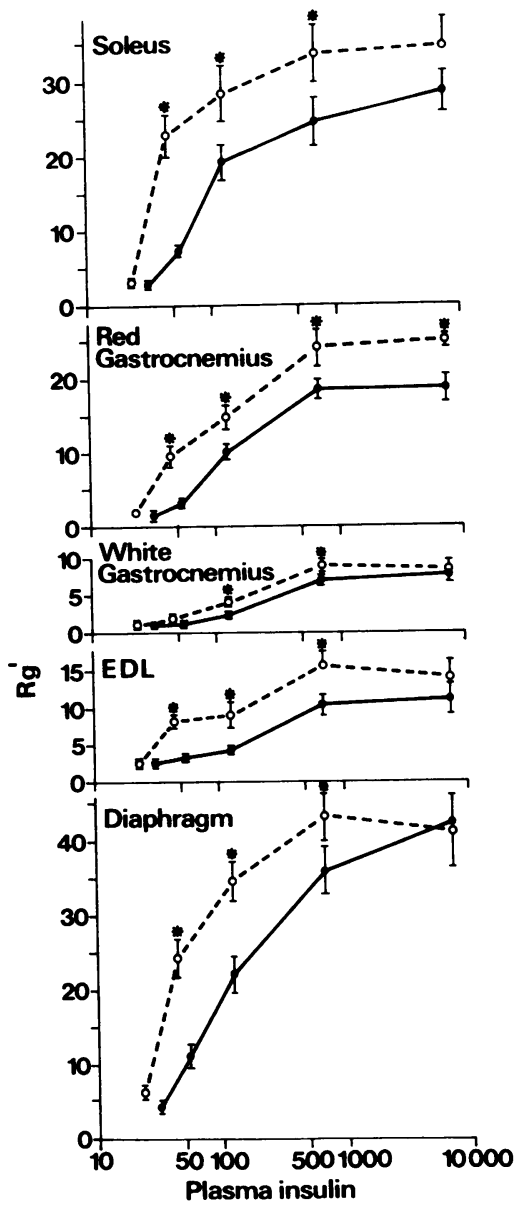

Figure 1. The effect of exercise training on the $\mathbf{R g}^{\prime}$ ( $\mu \mathrm{mol}$ [100 $g \cdot \mathrm{min}^{-1}$ ) in soleus, red and white gastrocnemius, EDL, and diaphragm. Chronically cannulated rats were constantly infused at different insulin doses $\left(\mathrm{mU} \cdot\right.$ liter $\left.^{-1}\right)$ while blood glucose was maintained at euglycemia for $2 \mathrm{~h}$. $\left[{ }^{3} \mathrm{H}\right] 2-\mathrm{DG}$ was administered as a bolus $45 \mathrm{~min}$ before the completion of the study while various tissues were rapidly removed for subsequent analysis. Each value is the mean \pm SEM of five to seven observations. $\bullet$, control animals; o, exercise-trained animals. *Significantly different from control at same plasma insulin concentration $(P<0.05)$.

trained rats to well within the physiological range of insulin concentrations (Table IV). However, increased maximal responsiveness to insulin was evident in soleus and red gastrocnemius from exercise-trained rats (Fig. 1). Further support for enhancement of insulin sensitivity is given by the relative magnitude of responses at submaximal insulin levels in these skeletal muscles (Fig. 1). In addition, there was some indication that insulin sensitivity in white gastrocnemius was also increased following training. First, $\mathbf{R g}^{\prime}$ in white gastrocnemius measured during insulin infusions at 3.6 and $14 \mathrm{mU}(\mathrm{kg} \cdot \mathrm{min})^{-1}$ was significantly higher $(P<0.025)$ in trained rats (Fig. 1). Furthermore, the doseresponse curve was noticeably shifted to the left as illustrated by the reduction in $\mathrm{ED}_{\mathbf{5 0}}$ (Table IV). However, no significant difference was found when the overall dose-response curves were compared using ANOVA; this was possibly due to the small range of variation with insulin compared with responses in other tissues (Fig. 1). On the basis of these observations, it seems that exercise training modulates the 
Table IV. Effect of Exercise Training on ED $D_{s 0}$ and Maximal Response of $\mathbf{R g}^{\prime}$ to Insulin in Different Skeletal Muscles

\begin{tabular}{|c|c|c|c|c|}
\hline \multirow[b]{2}{*}{ Muscle } & \multicolumn{2}{|l|}{$E_{\text {so }}$} & \multicolumn{2}{|c|}{ Maximal response } \\
\hline & Control & $\begin{array}{l}\text { Exercise- } \\
\text { trained }\end{array}$ & Control & $\begin{array}{l}\text { Exercise- } \\
\text { trained }\end{array}$ \\
\hline & $m U / l i t e r$ & mU/liter & \multicolumn{2}{|c|}{$\mu \mathrm{mol} / 100 \mathrm{~g} / \mathrm{min}$} \\
\hline Soleus & 86 & 37 & $26.2 \pm 2.1$ & $33.8 \pm 2.6^{*}$ \\
\hline \multicolumn{5}{|l|}{ Red } \\
\hline gastrocnemius & 133 & 51 & $19.3 \pm 2.4$ & $26.2 \pm 2.5^{*}$ \\
\hline \multicolumn{5}{|l|}{ White } \\
\hline gastrocnemius & 276 & 175 & $7.9 \pm 0.6$ & $8.7 \pm 0.7$ \\
\hline EDL & 315 & 44 & $11.5 \pm 1.3$ & $15.2 \pm 2.3$ \\
\hline Diaphragm & 126 & 37 & $43.5 \pm 5.1$ & $42.5 \pm 2.6$ \\
\hline
\end{tabular}

$\mathrm{ED}_{s 0}$ denotes the insulin concentration ( $m U /$ /iter) producing a halfmaximal increase in $\mathbf{R g}^{\prime}$. Maximum response denotes the $\mathbf{R} \mathbf{g}^{\prime}$ ( $\mu \mathrm{mol}$ ) $100 \mathrm{~g} \mathrm{per} \mathrm{min)} \mathrm{at} \mathrm{maximal} \mathrm{insulin} \mathrm{stimulation} \mathrm{in} \mathrm{five} \mathrm{different} \mathrm{skeletal}$ muscles of the rat. These data were calculated using a four parameter logistic function (see Methods).

* Significantly different from control values, $P<0.01$.

sensitivity to insulin in white gastrocnemius, albeit to a lesser extent than in other muscles.

Muscle hexokinase activity. Total hexokinase activity was measured in red gastrocnemius, EDL, and diaphragm of control and exercise-trained rats (Table V). Exercise training produced a significant increase in hexokinase activity in red gastrocnemius and diaphragm $(P<0.05)$ but not EDL.

Muscle glycogen content. The effect of different degrees of hyperinsulinemia on glycogen content in soleus in control and exercise-trained rats is shown in Fig. 2. Exercise training resulted in a significant elevation of soleus glycogen content in the basal state $(P<0.05)$. The difference observed in the basal state was maintained at higher insulin doses. However, there was no significant difference in the incremental effect of insulin on glycogen synthesis in soleus between control and exercise-trained rats at all four insulin doses.

Glucose storage in liver. Table VI displays liver glycogen content and fractional clearance of ${ }^{14} \mathrm{C}$ into liver glycogen and total nonpolar lipids at five different plasma insulin

Table V. Effect of Exercise Training on Muscle Hexokinase Activity

\begin{tabular}{lll}
\hline & \multicolumn{2}{l}{ Hexokinase activity } \\
\cline { 2 - 3 } Muscle & Control & Exercise-trained \\
\hline & $\mu \mathrm{mol}(\mathrm{g} \cdot \mathrm{min})^{-1}$ & $\mu \mathrm{mol}(\mathrm{g} \cdot \mathrm{min})^{-1}$ \\
Red gastrocnemius & $0.30 \pm 0.02(22)$ & $0.44 \pm 0.03 *(11)$ \\
EDL & $0.37 \pm 0.02(6)$ & $0.35 \pm 0.04(6)$ \\
Diaphragm & $0.34 \pm 0.02(6)$ & $0.43 \pm 0.03^{*}(6)$ \\
\hline
\end{tabular}

Hexokinase activity was measured in different skeletal muscles of control and exercise-trained rats. Values are means \pm SEM. The number of observations is indicated in parentheses.

* Significantly different from sedentary control values, $P<0.05$.
Soleus

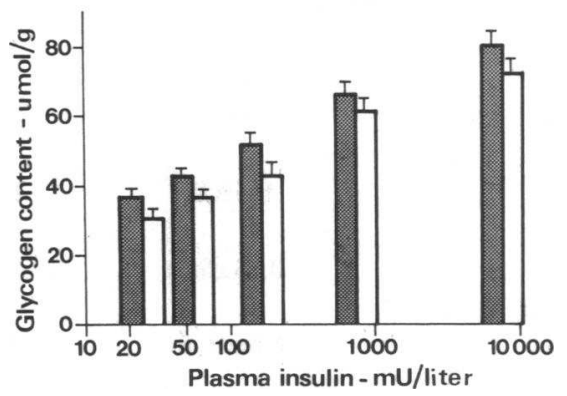

Figure 2. The effect of exercise training on glycogen content $(\mu \mathrm{mol} / \mathrm{g}$ ) in soleus. At the conclusion of the hyperinsulinemic euglycemic clamp, the soleus muscle was rapidly removed and frozen for measurement of glycogen content. Each value is the mean \pm SEM of five to seven observations. Clear bars represent control rats and shaded bars represent exercise-trained rats.

levels in control and exercise-trained rats. No significant effect of exercise training was detected on any of these parameters (Table VI).

Effects of exercise training in other tissues. The effect of insulin on the $\mathbf{R g}^{\prime}$ was also measured in lung, epididymal adipose tissue, and heart in both control and exercisetrained animals (Fig. 3). Rg' in epididymal adipose tissue was significantly higher in trained rats during insulin infusions at 3.6 and $14 \mathrm{mU}(\mathrm{kg} \cdot \mathrm{min})^{-1}$. It was not possible to obtain an estimate of $E D_{50}$ for the dose-response effect of insulin on $\mathbf{R g}^{\prime}$ in adipose tissue of trained rats due to the difficulty in accurately determining the maximal rate of insulin-stimulated $\mathrm{Rg}^{\prime}$ (Fig. 3). Despite the absence of an overall difference in the dose-response relationships of insulin-stimulated $\mathbf{R g}^{\prime}$ in heart between both groups, $\mathbf{R g}^{\prime}$ in the basal state was significantly reduced $(P<0.05)$ in exercise-trained rats.

In contrast, during insulin infusion at $1.4 \mathrm{mU}$ $(\mathrm{kg} \cdot \mathrm{min})^{-1}, \mathrm{Rg}^{\prime}$ in heart of exercise-trained rats was significantly higher than in sedentary controls (Fig. 3). At subsequent insulin doses, there was an anomalous fall in the heart $\mathbf{R g}^{\prime}$ in control and exercise-trained rats. A similar phenomenon was observed in adipose tissue from trained rats.

\section{Study B: Endogenous glucose production}

Table VII shows results of studies conducted in control and trained rats, infused with insulin at $2.4 \mathrm{mU}(\mathrm{kg} \cdot \mathrm{min})^{-1}$ and $\left[3-{ }^{3} \mathrm{H}\right]$ glucose, in which $\mathrm{Ra}$, both before and during the clamp, was measured. There was no significant difference in steady state blood glucose levels nor plateau insulin levels produced by insulin infusion between controls and exercise-trained rats.

Samples for estimation of plasma glucose specific activity were taken under conditions of steady state glucose flux in both the basal state and during the clamp. The mean coefficient of variation $( \pm \mathrm{SD})$ of glucose specific activity was $4.6 \pm 3.2 \%$ in the basal state and $6.4 \pm 1.8 \%$ during the hyperinsulinemic clamp. Ra under basal conditions and during hyperinsulinemia $(\sim 100 \mathrm{mU} /$ liter $)$ were similar in both groups of animals (Table VII). The average percent suppression of $\mathrm{Ra}$ during the clamp was $86.2 \pm 6.4 \%$ in 
Table VI. Effect of Exercise Training on Insulin-stimulated Fractional Incorporation of $\left[{ }^{14} \mathrm{C}\right]$ Glucose into Storage Products and on Liver Glycogen Mass in Liver

\begin{tabular}{|c|c|c|c|c|c|}
\hline \multicolumn{6}{|l|}{ Controls } \\
\hline Plateau insulin level $\left(m U \cdot\right.$ liter $\left.^{-1}\right)$ & 29 & 54 & 135 & 650 & 7500 \\
\hline \multicolumn{6}{|l|}{ Glycogen content } \\
\hline$\left(\mu \mathrm{mol} \cdot \mathrm{g}^{-1}\right)$ & $195 \pm 22$ & $190 \pm 16$ & $214 \pm 16$ & $256 \pm 32$ & $209 \pm 28$ \\
\hline \multicolumn{6}{|l|}{ Conversion to glycogen } \\
\hline (\% total cleared $/ g$ ) & $0.13 \pm 0.01$ & ND & $0.17 \pm 0.03$ & $0.13 \pm 0.02$ & $0.18 \pm 0.03$ \\
\hline \multicolumn{6}{|l|}{ Conversion to total lipids } \\
\hline (\% total cleared $/ g$ ) & $0.06 \pm 0.01$ & ND & $0.09 \pm 0.01$ & $0.11 \pm 0.02$ & $0.14 \pm 0.02$ \\
\hline \multicolumn{6}{|l|}{ Exercise-trained } \\
\hline Plateau insulin level $\left(m U \cdot\right.$ liter $\left.^{-I}\right)$ & 23 & 43 & 117 & 670 & 7400 \\
\hline Glycogen content $\left(\mu \mathrm{mol} \cdot \mathrm{g}^{-1}\right)$ & $225 \pm 18$ & $228 \pm 25$ & $231 \pm 25$ & $215 \pm 27$ & $264 \pm 27$ \\
\hline \multicolumn{6}{|l|}{ Conversion to glycogen } \\
\hline (\% total cleared $/ g$ ) & $0.18 \pm 0.02$ & ND & $0.18 \pm 0.02$ & $0.19 \pm 0.04$ & $0.20 \pm 0.05$ \\
\hline \multicolumn{6}{|l|}{ Conversion to total lipids } \\
\hline (\% total cleared $/ g)$ & $0.06 \pm 0.01$ & ND & $0.09 \pm 0.02$ & $0.09 \pm 0.02$ & $0.13 \pm 0.01$ \\
\hline
\end{tabular}

ND; not determined. Rats were sacrificed at the completion of 2 -h euglycemic clamp at the insulin level indicated. 45 min before the end of study, a $\left[{ }^{14} \mathrm{C}\right]$ glucose bolus was administered intravenously. Conversion to storage products indicated is expressed as a percentage of total $\left[{ }^{14} \mathrm{C}\right] \mathrm{glucose}$ cleared from the glucose pool in equilibrium with plasma over $45 \mathrm{~min}$. Values represent the mean $\pm \mathrm{SEM}$.

controls and $90.7 \pm 3.6 \%$ in exercise-trained rats. The exogenous glucose infusion rate required to maintain euglycemia and the tatal glucose disappearance rate were significantly higher $(P<0.025)$ in exercise-trained rats (Table VII), supporting the data obtained in study A (Table II).

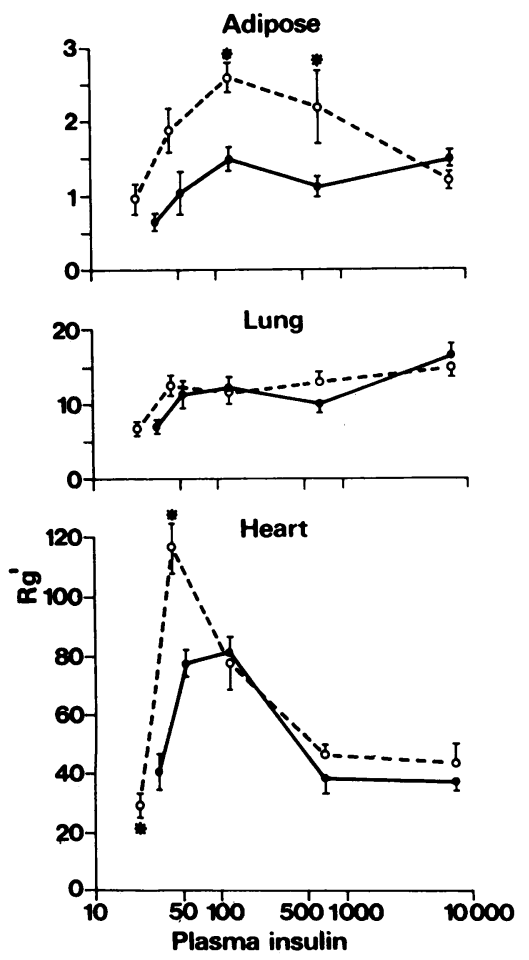

Figure 3. The effect of exercise training on insulin $\left(m U \cdot\right.$ liter $\left.^{-1}\right)$ stimulated $\mathrm{Rg}^{\prime}\left(\mu \mathrm{mol}[100 \mathrm{~g} \cdot \mathrm{min}]^{-1}\right.$ ) in adipose tissue, lung, and heart. For experimental details, see Fig. 1. Each value is the mean \pm SEM of five to seven observations. ๑, control rats; 0 , exercisetrained rats. *Significantly different from control value at same plasma insulin concentration $(P<0.05)$.
Muscle glycogen synthesis. A more extensive investigation of the effect of exercise training on muscle glycogen synthesis has been conducted in this study in which glycogen content and $\left[{ }^{14} \mathrm{Clglucose}\right.$ incorporation into glycogen have been measured in four different hindlimb muscles in the basal state and during hyperinsulinemia $(\sim 100 \mathrm{mU} /$ liter $)$ (Table VIII). As was found in study A (Fig. 2), soleus glycogen content in the basal state and during hyperinsulinemia was significantly higher $(P<0.05)$ in trained rats (Table VIII). However, $\left[{ }^{14} \mathrm{C}\right]$ glucose incorporation into glycogen in soleus, which effectively represents only glycogen synthesized over the period of observation and thus eliminates the contribution of basal levels, was similar in trained and untrained rats (Table VIII). This substantiates the observation (study A) that insulin-stimulated glycogen synthesis in soleus of trained rats is not significantly different

Table VII. Effect of Exercise Training on Whole Body Glucose Turnover during a Hyperinsulinemic Euglycemic Clamp

\begin{tabular}{lcc}
\hline & Control & Exercise-trained \\
\hline Body weight $(\mathrm{g})$ & $357 \pm 8$ & $355 \pm 8$ \\
Blood glucose $\left(\mathrm{mmol}^{\circ} \cdot \mathrm{liter}^{-1}\right)$ & & \\
$\quad$ Fasting & $4.1 \pm 0.1$ & $4.1 \pm 0.1$ \\
$\quad$ Steady state & $4.1 \pm 0.1$ & $4.2 \pm 0.1$ \\
Plasma insulin $\left(\mathrm{mU} \cdot \mathrm{liter}{ }^{-1}\right)$ & & \\
$\quad$ Fasting & $28 \pm 3$ & $22 \pm 5$ \\
$\quad$ Steady state & $98 \pm 9$ & $105 \pm 3$ \\
GIR $60-120\left(\mathrm{mg} \cdot\left[\mathrm{kg} \cdot \mathrm{min}^{-1}\right)\right.$ & $13.5 \pm 1.9$ & $18.2 \pm 1.3^{*}$ \\
Ra $\left(\mathrm{mg} \cdot[\mathrm{kg} \cdot \mathrm{min}]^{-1}\right)$ & & \\
$\quad$ Basal & $6.9 \pm 0.9$ & $6.2 \pm 0.6$ \\
Clamp & $0.8 \pm 0.5$ & $0.6 \pm 0.3$ \\
Rd $\left(\mathrm{mg} \cdot[\mathrm{kg} \cdot \mathrm{min}]^{-1}\right)$ & $14.3 \pm 1.7$ & $18.7 \pm 1.0^{*}$ \\
\end{tabular}

Rd, net glucose utilization.

All values represent mean \pm SEM of five observations.

* Significantly different from control: $P<0.025$. 
Table VIII. Effect of Insulin on Glucose Incorporation into Muscle Glycogen and Muscle Glycogen Content in Control and Exercisetrained Rats

\begin{tabular}{|c|c|c|c|c|}
\hline \multirow[b]{3}{*}{ Muscle } & \multicolumn{4}{|c|}{ Insulin dose $\left(m U[k g \cdot m i n]^{-l}\right)$} \\
\hline & 0 & 2.4 & 0 & 2.4 \\
\hline & \multicolumn{2}{|c|}{$\begin{array}{l}\text { Glucose incorporation into } \\
\text { glycogen } \\
(\mu \mathrm{mol} / 100 \mathrm{~g} / \mathrm{min})\end{array}$} & \multicolumn{2}{|c|}{$\begin{array}{l}\text { Glycogen content } \\
(\mu \mathrm{mol} / \mathrm{g})\end{array}$} \\
\hline \multicolumn{5}{|l|}{ Soleus } \\
\hline Control & $1.0 \pm 0.1$ & $10.4 \pm 0.9$ & $33.1 \pm 1.9$ & $44.1 \pm 3.2$ \\
\hline ET & $0.6 \pm 0.1$ & $10.0 \pm 1.3$ & $38.3 \pm 1.5^{*}$ & $55.0 \pm 3.2^{*}$ \\
\hline \multicolumn{5}{|c|}{ Red gastrocnemius } \\
\hline Control & $0.4 \pm 0.1$ & $5.8 \pm 0.8$ & $36.7 \pm 2.4$ & $48.6 \pm 2.6$ \\
\hline ET & $0.4 \pm 0.1$ & $6.9 \pm 1.1$ & $39.9 \pm 1.4$ & $53.2 \pm 3.5$ \\
\hline \multicolumn{5}{|c|}{ White gastrocnemius } \\
\hline Control & $0.09 \pm 0.02$ & $1.03 \pm 0.27$ & $38.1 \pm 1.9$ & $41.2 \pm 3.4$ \\
\hline ET & $0.10 \pm 0.01$ & $0.85 \pm 0.13$ & $43.0 \pm 3.9$ & $44.1 \pm 3.0$ \\
\hline \multicolumn{5}{|l|}{ EDL } \\
\hline Control & $1.1 \pm 0.1$ & $2.6 \pm 0.5$ & $30.7 \pm 1.9$ & $38.6 \pm 2.9$ \\
\hline ET & $0.6 \pm 0.1$ & $4.7 \pm 1.0^{*}$ & $33.2 \pm 2.1$ & $45.7 \pm 2.4^{*}$ \\
\hline
\end{tabular}

ET, exercise-trained. Glycogen content and $\left[{ }^{14} \mathrm{C}\right] g l u c o s e$ incorporation into glycogen were measured in four hindquarter muscles which were rapidly removed and frozen at the conclusion of the euglycemic clamp. $\left[{ }^{14} \mathrm{C}\right]$ glucose was administered as a bolus at $75 \mathrm{~min}$ after the commencement of the clamp. $\left[{ }^{14} \mathrm{C}\right]$ glucose incorporation into muscle glycogen was calculated using Eq. 2 . Values are means \pm SEM of seven to eight observations. ${ }^{*}$ Significantly different from control value: $P$ $<0.05$ ).

from that seen in controls. Similarly, there was no significant difference in insulin-stimulated glycogen synthesis in red and white gastrocnemius between control and trained rats (Table VIII). However, in EDL, both glycogen content and $\left[{ }^{14} \mathrm{C}\right]$ glucose incorporation into glycogen during insulin infusion were significantly higher $(P<0.05)$ in exercisetrained rats (Table VIII).

$\left.{ }^{14} \mathrm{C}\right]$ Glucose into lipid products. Fig. 4 shows the effect of insulin on the fractional clearance of ${ }^{14} \mathrm{C}$ into glyceride glycerol and FFA in liver and epididymal adipose tissue of control and exercise-trained rats. First, there is a marked contribution of $\left[{ }^{14} \mathrm{C}\right]$ glycerol to the total lipid extract in both liver and adipose tissue. Confirming the data reported in study $\mathrm{A}$, there was no significant difference in insulinstimulated fractional clearance of ${ }^{14} \mathrm{C}$ into either the FFA or glycerol fraction in the liver between control and exercisetrained rats. In contrast, epididymal adipose tissue from trained rats displayed a significantly higher increase in the $\left[{ }^{14} \mathrm{C}\right]$ FFA fraction during hyperinsulinemia compared with the control group (Fig. 4). Under basal conditions, ${ }^{14} \mathrm{C}$ clearance into FFA in adipose was unaffected by training, whereas ${ }^{14} \mathrm{C}$-clearance into the glycerol moiety was significantly reduced $(P<0.05)$.

\section{Discussion}

The effect of exercise training on the relative insulin sensitivity of different tissues of the body has not previously been determined. In the present studies, by combining tracer ad-

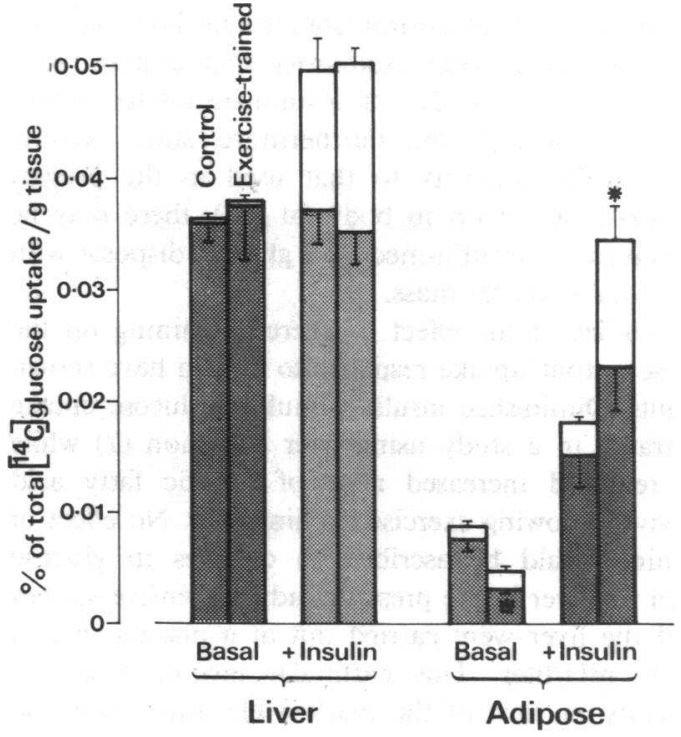

Figure 4. The effect of exercise training on the incorporation of $\left[{ }^{14} \mathrm{C}\right]$ glucose into the FFA moiety (clear bars) and the glyceride glycerol moiety (shaded bars) of liver and epididymal adipose tissue. Chronically cannulated rats were studied either in the basal state (no exogenous insulin) or during a hyperinsulinemic clamp (plasma insulin of $\sim 100 \mathrm{mU} \cdot$ liter $\left.^{-1}\right)$. $\left[{ }^{14} \mathrm{C}\right]$ glucose was administered as a bolus 45 min before the completion of the study while the above tissues were rapidly removed for analysis. Each value is the mean \pm SEM of six to eight observations. *Significantly different from control value $(P<0.05)$

ministration with the euglycemic clamp technique, it has been found that exercise training produces a marked increase in the capacity of different skeletal muscles for insulin-stimulated glucose disposal, a small increase in adipose tissue, and no effect in the liver. The predominant effect of exercise training on whole body insulin action occurs within the physiological range of plasma insulin as indicated by a shift in the $E D_{50}$ for insulin-stimulated glucose disposal from $150 \mathrm{mU} /$ liter in controls to $50 \mathrm{mU} /$ liter in trained rats (2). Similarly, the major effect of training on the dose-response relationship between plasma insulin and $\mathbf{R g}^{\prime}$ in skeletal muscle was an increase in insulin sensitivity with a marked decline in $\mathrm{ED}_{50}$ values in all muscles tested to well within the physiological range of insulin concentration (Table IV). In view of the large effects of exercise training on insulin action in muscle (Fig. 1) and the major role of this tissue as a site for insulin-stimulated glucose disposal $(17,25)$, there is no doubt that skeletal muscle is the primary tissue responsible for the enhanced whole body insulin sensitivity that results from exercise training.

In addition to these effects in muscle, there was also a significant effect of exercise training on insulin-stimulated $\mathbf{R g}^{\prime}$ in epididymal fat (Fig. 3). However, in view of the slight elevation in basal $\mathrm{Rg}^{\prime}$ in adipose tissue of trained rats (Fig. 3), it was difficult to accurately assess the difference in incremental effects of insulin between control and trained rats. To resolve this, a more extensive investigation of $\left[{ }^{14} \mathrm{C}\right]$ glucose clearance into FFA in epididymal fat was conducted (Fig. 4). These studies clearly indicate a significant increase in insulin action in adipose tissue following exercise training. Although these effects of training in adipose tissue have significant implications from a mechanistic viewpoint, they are unlikely to have any 
significant bearing on insulin-stimulated whole body glucose disposal. It has previously been established that adipose tissue could at most account for $2 \%$ of insulin-stimulated whole body glucose disposal $(12,26)$. Furthermore, since exercise training of a similar intensity to that used in the present studies produces a reduction in body fat (27), there may be little or no increase in insulin-mediated glucose disposal with respect to the total body fat mass.

Previous studies of the effect of exercise training on the hepatic glucose output/uptake response to insulin have shown divergent results. Diminished insulin-stimulated glucose uptake was demonstrated in a study using liver perfusion (7) while others have reported increased rates of hepatic fatty acid synthesis in vivo following exercise training (28). No effect of exercise training could be ascribed to changes in glucose metabolism in the liver in the present study. Extensive studies of the role of the liver were carried out at a plasma insulin level of $\sim 100 \mathrm{mU} /$ liter. This particular insulin dose was selected for study in view of the marked elevation in whole body net glucose utilization in trained versus untrained rats between 50 and $150 \mathrm{mU} / \mathrm{liter}$ of insulin (Table II). Liver glycogen storage (Table VI), $\left[{ }^{14} \mathrm{C}\right]$ glucose incorporation into liver lipids (Fig. 4), and suppression of hepatic glucose output (Table VII) were not significantly different from that seen in sedentary controls.

Dose-response curves of insulin-mediated $\mathrm{Rg}^{\prime}$ were also measured in lung from control and exercise-trained rats (Fig. 3). As with liver, there was no apparent effect of training in this tissue.

The effect of exercise training on insulin action in heart was also of considerable interest (Fig. 3). The significant reduction in $\mathbf{~ R g}^{\prime}$ under basal conditions in exercise-trained rats may be related to the lower basal insulin levels (Table I) or to an increased dependence on FFA as an energy yielding substrate. In contrast, at the lowest insulin infusion rate, $\mathbf{R} \mathbf{g}^{\prime}$ in heart was significantly higher in trained rats. In view of the heart's large fuel requirement, even in resting animals, part of this incremental effect of insulin may be related to inhibition of lipolysis with increased glucose utilization compensating for reduced supply of FFA from the blood. This concept has previously been discussed with respect to insulin action in other tissues (12). At supraphysiological insulin levels, there was a decline in $\mathrm{Rg}^{\prime}$ in the heart of both control and trained rats (Fig. 3). This anomalous effect, which has been reported elsewhere (29), has not been explained but could be related to feedback inhibition of tissue glycogen on glucose transport or altered ionic flux in the heart. The physiological relevance of the effect is questionable.

The increased extraction of $\left[{ }^{3} \mathrm{H}\right] 2 \mathrm{DG}$ by skeletal muscle in exercise-trained rats, particularly within the physiological range of insulin concentrations, resulted in a significant reduction in the $\left[{ }^{3} \mathrm{H}\right] 2 \mathrm{DG}$ concentration remaining in plasma at $45 \mathrm{~min}$ after tracer administration (Table III). Thus the increased individual tissue uptakes in the trained group are consistent with altered $\left[{ }^{3} \mathrm{H}\right] 2 \mathrm{DG}$ kinetics at the whole body level. The fact that the final $\left[{ }^{3} \mathrm{H}\right] 2 \mathrm{DG}$ remaining in plasma is a more sensitive parameter of discrimination than the area under the $\left[{ }^{3} \mathrm{H}\right] 2 \mathrm{DG}$ curve (Table III) may reflect the precise metabolic locus of action of the training effect (e.g., glucose transport versus post-transport events). This observation requires further study using a suitable glucose kinetic model.

When considering the effects of exercise training on skeletal muscle, it is worth noting that the enhanced insulin sensitivity occurs to a greater extent in oxidative skeletal muscle, such as soleus and red gastrocnemius, compared with glycolytic muscles, such as white gastrocnemius (Fig. 1). This finding is consistent with our hypothesis (17) that an important determinant of whole body insulin sensitivity is the ratio of oxidative to glycolytic muscle fibers which constitute the skeletal muscle mass. This is not to say that the improved insulin sensitivity in skeletal muscle with training is due to conversion of glycolytic fibers into oxidative fibers (30). In fact, considering that the soleus in control animals is composed almost completely of oxidative fibers (15), it is unlikely that fiber interconversion could account for the marked effect on insulin sensitivity in the soleus of trained rats (Fig. 1).

There was also evidence of increased insulin sensitivity following training in muscles containing mainly glycolytic muscle fibers (EDL and white gastrocnemius), albeit to a lesser extent than that observed in the more oxidative muscles (Fig. 1). This is important since the type of exercise used in the present studies is not of sufficient intensity to activate the high threshold fast-twitch glycolytic muscle fibers. In fact, we have previously shown, by estimating glycogen depletion and $\mathbf{R g}^{\prime}$ in different muscles, that during treadmill exercise of similar intensity to that used in the present training program, EDL and white gastrocnemius are not recruited at this workload (31). These observations are consistent with the hypothesis that the increased insulin sensitivity, which accompanies exercise training, may be mediated at least in part via systemic factors. However, due to the possibility of marginal recruitment of these muscle fibers and the magnitude of the enhanced insulin sensitivity in muscles which are predominantly involved during exercise of this intensity (31), namely soleus and red gastrocnemius, it is likely that these effects are mediated primarily via local factors. Modulation via systemic factors may explain the marked increase in insulin-stimulated $\left[{ }^{14} \mathrm{C}\right]$ glucose incorporation into FFA in epididymal adipose tissue of exercise-trained rats (Fig. 4). Although it has been proposed that altered insulin action in adipocytes may simply be due to changes in cell size, there is much evidence that such effects occur independently of reduced body weight or fat cell size following training $(4,8,32)$. Therefore, a systemic effect of exercise training is probably the simplest explanation for these adaptations in nonexercising tissues.

This study does not provide the detailed cellular biochemical measurements required to precisely identify the mechanism of the improved insulin action in trained animals. Nevertheless, information available from the study does have an important bearing on the likely mechanisms. Reduced adiposity is known to improve insulin sensitivity; however, we have previously demonstrated (2) that the improvement in whole body insulin sensitivity due to exercise training is apparent whether the comparison is with controls fed ad lib. or with food-restricted weight-matched controls. Thus the effect of training in the present study cannot be attributed to the reduced body weight of the trained animals. It has also been shown that the effects of a single bout of exercise on insulin levels and glucose tolerance in rats is no longer evident after $24 \mathrm{~h}$ (14). Thus the present studies, which were performed more than $48 \mathrm{~h}$ after the last exercise bout, should reflect an adaptation to chronic exercise training rather than the effects of the last bout of exercise. With regard to the question of an effect at the insulin receptor versus postreceptor effects, it has been suggested that 
an improvement in maximal insulin responsiveness cannot be explained on the basis of changes in insulin receptors, while improved sensitivity may be attributed to receptor or postreceptor mechanisms. In the whole body response (2), an improvement in sensitivity but not maximal responsiveness was demonstrated. However, an improvement in maximal responsiveness is evident in some individual muscles (Fig. 1, Table IV). Thus it seems likely that exercise training affects postreceptor events, though this does not exclude a complementary effect on insulin receptors which has been demonstrated by some $(4,8,33)$ but not all $(5,34)$ groups.

One possibility to account for the improved insulin sensitivity is that the hypoinsulinemia of exercise training (Table I) may produce an "upregulation" of the insulin receptor. Interestingly, in the present studies, there was a significant negative correlation between the steady state glucose infusion rate obtained at the midpoint of the dose-response curves and basal plasma insulin concentration in trained and untrained rats $(r$ $=-0.57, P<0.05$ ); of course, one could also argue that the improved insulin sensitivity is the cause of the hypoinsulinemia. Other factors that could affect insulin sensitivity are the counterregulatory hormones, which are released in response to each exercise bout. It has been shown that animals injected with epinephrine each day for 6 wk displayed some adaptive responses similar to those observed following training (35). Furthermore, recent evidence indicates that the administration of a $\beta$-adrenergic blocker during a hyperinsulinemic clamp in man resulted in a significant decrease in insulin-mediated glucose oxidation (36). Whether there are alterations in catecholamine sensitivity in muscle or in adrenergic tonus during hyperinsulinemia in exercise-trained rat is yet to be determined.

Insulin-stimulated glycogen synthesis in the soleus and red and white gastrocnemius was not significantly altered by exercise training, whereas in EDL, there was a marginal increase in insulin-stimulated glycogen synthesis following training (Fig. 2; Table VIII). Thus, it is reasonable to conclude that the increased capacity of skeletal muscle from exercisetrained rats for insulin-stimulated glucose disposal (Fig. 1) is largely due to enhanced glucose oxidation. However, it is important to note that the present studies were conducted 48 $h$ after the last bout of exercise, at which time muscle glycogen levels were fully replete (2). To properly assess the insulin sensitivity of muscle glycogen synthesis in exercise-trained rats, it may be necessary to repeat these studies within $24 \mathrm{~h}$ of the last exercise bout. However, under these circumstances, it becomes difficult to distinguish between a chronic training effect versus an acute effect of one bout of exercise. In fact, Richter et al. (37) have shown that insulin-stimulated muscle glucose uptake and glycogen synthesis are enhanced for several hours after a single bout of exercise in untrained rats. Taking these findings together, it is likely that the primary adaptation following training is a long lasting elevation in muscle glucose uptake. In the postexercise recovery phase, this adaptation would obviously ensure rapid glycogen repletion in muscle. However, once glycogen levels are returned to normal or even supranormal levels, further glycogen synthesis may be inhibited resulting in a redirection of glucose flux via glycolytic and oxidative pathways. These observations are in agreement with previous in vitro studies, conducted between 24 and $44 \mathrm{~h}$ after the last bout of exercise, showing increased insulin sensitivity of glycolysis with no change in glycogen synthesis in isolated soleus muscle from exercise-trained rats $(5,6)$. This is consistent with a reduced insulin response to a glucose load $(3,14)$ in exercise-trained rats. This chronic effect may be responsible for the expenditure of excess calories in the postprandial state and thus discourage the flux of nutrients to fat.

Although one could suggest the increased glucose oxidation is purely secondary to augmentation of insulin-induced glucose transport, it is well established that training induces adaptations in muscle enzymes capable of affecting the rate of glucose oxidation. Amongst a number of biochemical adaptations (38), there is a marked increase in some muscles in many of the enzymes regulating oxidative capacity. These enzymatic changes have not been rigorously examined in the present study. However, there was no correlation between hexokinase activity and the augmented response to insulin within different muscles (Table V).

The effect of exercise training on skeletal muscle blood flow has not been examined in the present study. However, others have been unable to demonstrate any significant change in resting muscle blood flow following training (39). Other factors which may influence glucose oxidation in muscle are substrate cycling and ionic flux. The metabolic consequences of substrate cycles have been discussed by Newsholme (40). However, their quantitative significance in skeletal muscle has not been examined. Changes in the ionic composition of exercise-trained skeletal muscle have previously been reported (41). In addition, both $\mathrm{Ca}^{2+}$ and $\mathrm{K}^{+}$have been shown to modulate glucose uptake in isolated muscle $(42,43)$. However, the relationship between ionic flux and insulin action in vivo has not been established.

In conclusion, exercise training produces a marked increase in whole body insulin sensitivity, primarily due to increased insulin-mediated glucose oxidation in skeletal muscle. This effect would undoubtedly alter the distribution of glucose towards muscle utilization in the postprandial state and this emphasizes the potential benefit of exercise in the prevention and treatment of a number of disorders such as noninsulindependent diabetes and obesity where insulin resistance is thought to be a significant problem.

\section{Acknowledgments}

The authors are grateful for the expert technical assistance of Mrs. Kathy Burleigh, Mr. Steve Bennett, and Mr. Walter Tok; and for the secretarial assistance of Ms. Carol Farnell and Ms. Hilary Cox.

This work has been supported by a Program Grant from the National Health and Medical Research Council of Australia and the John Claude Kellion Foundation.

\section{References}

1. Soman, V. R., V. A. Koivisto, D. Deibert, P. Felig, and R. Defronzo. 1979. Increased insulin sensitivity and insulin binding to monocytes after physical training. $N$. Engl. J. Med. 301:1200-1204.

2. James, D. E., E. W. Kraegen, and D. J. Chisholm. 1984. The effect of exercise training on whole body insulin sensitivity and responsiveness. J. Appl. Physiol. 56:1217-1222.

3. Berger, M., F. W. Kemmer, K. Becker, L. Herberg, M. Schwener, A. Gjinavci, and P. Berchtold. 1979. Effect of physical training on glucose tolerance and on glucose metabolism of skeletal muscle in anaesthetised normal rats. Diabetologia. 16:179-184.

4. Craig, B. W., G. T. Hammons, S. M. Garthwaite, L. Jarrett, and J. O. Holloszy. 1981. Adaptation of fat cells to exercise: response 
of glucose uptake and oxidation to insulin. J. Appl. Physiol. 51:15001506.

5. Crettaz, M., E. S. Horton, L. J. Wardzala, E. D. Horton, and B. Jeanrenaud. 1983. Physical training of Zucker rats: lack of alleviation of muscle insulin resistance. Am. J. Physiol. 244:E414-E420.

6. Espinal, J., G. L. Dohm, and E. A. Newsholme. 1983. Sensitivity to insulin of glycolysis and glycogen synthesis of isolated soleus-muscle strips from sedentary, exercised and exercise-trained rats. Biochem. $J$. 212:453-458.

7. Mondon, C. E., C. B. Dolkas, and G. M. Reaven. 1980. Site of enhanced insulin sensitivity in exercise trained rats at rest. Am. $J$. Physiol. 239:E169-E177.

8. Vinten, J., and H. Galbo. 1983. Effect of physical training on transport and metabolism of glucose in adipocytes. Am. J. Physiol. 244:E129-E134.

9. Wardzala, L. J., M. Crettaz, E. D. Horton, B. Jeanrenaud, and E. S. Horton. 1982. Physical training of lean and genetically obese Zucker rats: effect on fat cell metabolism. Am. J. Physiol. 243:E418E426.

10. Defronzo, R. A., E. Ferrannini, R. Hendler, P. Felig, and J. Wahren. 1983. Regulation of splanchnic and peripheral glucose uptake by insulin and hyperglycaemia in man. Diabetes. 32:35-45.

11. Thiebaud, D., E. Jacot, R. A. Defronzo, E. Maeder, E. Jequier, and J. P. Felber. 1982. The effect of graded doses of insulin on total glucose uptake, glucose oxidation and glucose storage in man. Diabetes. 31:957-963.

12. Kraegen, E. W., D. E. James, A. B. Jenkins, and D. J. Chisholm. 1985. Dose response curves for in vivo insulin sensitivity in individual tissues in rats. Am. J. Physiol. 248:E353-E362.

13. Kraegen, E. W., D. E. James, S. P. Bennett, and D. J. Chisholm. 1983. In vivo insulin sensitivity in the rat determined by euglycemic clamp. Am. J. Physiol. 245:E1-E7.

14. James, D. E., K. M. Burleigh, E. W. Kraegen, and D. J. Chisholm. 1983. Effect of acute exercise and prolonged training on the insulin response to intravenous glucose in vivo in the rat. J. Appl. Physiol. 55:1660-1664.

15. Ariano, M. A., R. B. Armstrong, and V. R. Edgerton. 1973. Hindlimb muscle fiber populations of five mammals. J. Histochem. Cytochem. 21:51-55.

16. Hickson, R. C., W. W. Heusner, W. O. Van Huss, J. F. Taylor, and R. E. Carrow. 1976. Effects of an anabolic steroid and sprint training on selected histochemical and morphological observations in rat skeletal muscle types. Eur. J. Appl. Physiol. 35:251-259.

17. James, D. E., A. B. Jenkins, and E. W. Kraegen. 1985. Heterogeneity of insulin action in individual muscles in vivo: studies using the euglycemic clamp technique in rats. Am. J. Physiol. 248: E567-E574.

18. Brunengraber, H., M. Boutry, and J. M. Lowenstein. 1973. Fatty acid and 3-hydroxysterol synthesis in the perfused rat liver. $J$. Biol. Chem. 248:2656-2669.

19. Morgan, C. R., and A. Lazarow. 1963. Immunoassay of insulin: two antibody system: plasma insulin levels of normal, subdiabetic, and diabetic rats. Diabetes. 12:115-126.

20. Carr, P. J., R. P. Millar, and H. Crowley. 1977. A simple radioimmunoassay for plasma cortisol: comparison with the fluorimetric method of determination. Ann. Clin. Biochem. 14:207-211.

21. Chan, T. M., and J. H. Exton. 1976. A rapid method for the determination of glycogen content and radioactivity in small quantities of tissue or isolated hepatocytes. Ann. Biochem. 71:96-105.

22. Stauffacher, W., and A. E. Renold. 1969. Effect of insulin in vivo on diaphragm and adipose tissue of obese mice. Am. J. Physiol. 216:98-105.

23. Shonk, C. E., and G. E. Boxer. 1964. Enzyme patterns in human tissues. I. Methods for the administration of glycolytic enzymes. Cancer Res. 24:709-721.

24. DeLean, A., P. J. Munson, and D. Rodbard. 1978. Simultaneous analysis of families of sigmoidal curves: application to bioassay, radioligand assay and physiological dose-response curves. Am. J. Physiol. 235:E97-E102.

25. Defronzo, R. A., E. Jacot, E. Jequier, E. Maeder, J. Wahren, and J. P. Felber. 1981. The effect of insulin on the disposal of intravenous glucose. Results from indirect calorimetry and hepatic and femoral venous catheterization. Diabetes. 30:1000-1007.

26. Björntorp, P., and L. Sjöstrom. 1978. Carbohydrate storage in man. Speculations and some quantitative considerations. Metab. Clin. Exp. 27(Suppl. 2):1853-1865.

27. James, D. E., and E. W. Kraegen. 1984. The effect of exercise training on glycogen, glycogen synthase and phosphorylase in muscle and liver. Eur. J. Appl. Physiol. 52:276-281.

28. Tokuyama, K., and H. Okuda. 1983. Fatty acid synthesis in adipose tissues of physically trained rats in vivo. Am. J. Physiol. 245(8):E8-E13.

29. James, D. E., E. W. Kraegen, K. Burleigh, and D. J. Chisholm. 1985. In vivo dose response curves of insulin action in heart: anomalous effects at high insulin doses. Mol. Cell. Cardiol. In press.

30. Jansson, E., and L. Kaijser. 1977. Muscle adaptations to extreme endurance training in man. Acta Physiol. Scand. 100:315324.

31. James, D. E., E. W. Kraegen, and D. J. Chisholm. 1985. Muscle glucose metabolism in exercising rats: comparison with insulin stimulation. Am. J. Physiol. 248:E575-E580.

32. Owens, J. L., E. O. Fuller, D. O. Nutter, and M. Di Girolamo. 1977. Influence of moderate exercise on adipocyte metabolism and hormonal responsiveness. J. Appl. Physiol. 43:425-430.

33. Le Blanc, J., A. Nadeau, M. Boulay, and S. RousseauMigneron. 1979. Effects of physical training and adiposity on glucose metabolism and ${ }^{125}$ I-binding. J. Appl. Physiol. 46:235-239.

34. Wirth, A., G. Holm, B. Nilsson, U. Smith, and P. Björntorp. 1980. Insulin kinetics and insulin binding to adipocytes in physically trained and food restricted rats. Am. J. Physiol. 238:E108-E115.

35. Fell, R. D., S. E. Terblanche, W. W. Winder, and J. O. Holloszy. 1981. Adaptive responses of rats to prolonged treatment with epinephrine. Am. J. Physiol. 241:C55-C58.

36. Defronzo, R. A., D. Thorin, J. P. Felber, D. C. Simonson, D. Thiebaud, E. Jequier, and A. Golay. 1984. Effect of beta and alpha adrenergic blockade on glucose-induced thermogenesis in man. J. Clin. Invest. 73:633-639.

37. Richter, E. A., L. P. Garetto, M. N. Goodman, and N. B. Ruderman. 1982. Muscle glucose metabolism following exercise in the rat: increased sensitivity to insulin. J. Clin. Invest. 69:785-793.

38. Holloszy, J. O., and F. W. Booth. 1976. Biochemical adaptations to endurance exercise in muscle. Ann. Rev. Physiol. 38:273-291.

39. Armstrong, R. B., and M. H. Laughlin. 1984. Exercise blood flow patterns within and among rat muscles after training. Am. J. Physiol. 246:H59-H68.

40. Newsholme, E. 1978. Substrate cycles: their metabolic, energetic and thermic consequences in man. Biochem. Soc. Symp. 43:183-205.

41. Jaweed, M. M., R. C. De Groo, G. J. Herbison, J. F. Ditunno, Jr., and C. P. Bianchi. 1983. Muscle electrolyte changes in young exercised rats. In Biochemistry of Exercise, Vol. 13. H. Knuttgen, editor. Human Kinetics Publishers, Champaign, IL. 557-563.

42. Holloszy, J. O., and H. T. Narahara. 1967. Enhanced permeability to sugar associated with muscle contraction. Studies of the role of $\mathrm{Ca}^{++}$. J. Gen. Physiol. 50:551-562.

43. Valant, P., and D. Erlij. 1983. $\mathrm{K}^{+}$-stimulated sugar uptake in skeletal muscle: role of cytoplasmic $\mathrm{Ca}^{2+}$. Am. J. Physiol. 245:C125C132. 